number of ventral tentacles, With these were numerous specimens of an interesting species of Euphronides. In this haul I was specially struck with the Elasipoda, and the great variety in the consistency of the skin in individuals of one and the same species; it varied in different individuals from extreme tenuity to a comparatively tough gelatine-like consistency. On carefully sifting the mud, we found a number of interesting Foraminifera, and of delicate and minute Gasteropods and Lamellibranchs, fragments of the shell of an Argonauta, and two species of a huge ribbed Dentalium. Among the Star-fishes were specially noticeable a large Brisinga, a long-armed Cribrella, and several species of Astropecten. The usual types of Worms were found in the mud at these greater depths. In addition to a number of Macruroids, we obtained a pink Amphionus, a large black Beryx-like fish, a fine Nettastoma, and a couple of species of Lycodes. The usual surface species of Stomias and of Scopelus also came up in the trawl. Among the Crustaceans were a fine lot of Arcturus, of Colossendeis, of Glyphocrangon, and of a Caridid with a deep blue patch on the base of the carapace, making the strongest possible contrast to the dark crimson colouring of the rest of the body. Blue is a very unusual colour in the deep-sea types, although the large eggs of some of the deep-sea Macrurans are often of a light blue tint.

We brought up in the trawl at various times, and subsequently also in the Tanner net, from depths of less than 200 fathoms, the same gigantic Ostracod which I mentioned in one of my previous letters, several specimens of Atolla, and fragments of a huge Periphylla, which must have been at least $\mathrm{r}_{5}$ inches in diameter. Also a most interesting new type of Bougainvillia, remarkable for having eight clusters of marginal tentacles, but only four chymiferous tubes.

We continued our experiments with the Tanner tow-net. On April I6, about 120 miles from Acapulco, we sent the net to tow at a depth of 175 fathoms, and after towing for about twenty minutes, sent the messenger to close it. On examining the bottom part of the net, which came up tightly closed, we found it to contain practically the same things as we obtained in the surface net at the same spot.

On two occasions we sent the net to be towed at depths of 800 fathoms and of 700 fathoms, the depths at these points being in one case 905 fathoms and in the other 773 fathoms. At the greater depth, the water shoaled somewhat while towing, as the closed part of the net came up partly filled with fine silt while during the second haul, the twisting of the swivel wound the straps of the weights round the rope, and the net came up open, but must have dragged very close to the bottom, as it contained a fine specimen of Nettastoma, and some Penæids, which we supposed to be deep-sea types. Otherwise the net contained only the customary surface species of Sagitta, Pteropods, Copepods, Schizopods, Tunicates, and Fishes. These two hauls were made about the middle of the Gulf of California, at a distance of some fifty miles in a south-westerly direction from Guaymas.

On April 23, a few hours before reaching Guaymas, we made one more attempt with the Tanner tow-net, at a depth of 620 fathoms, sending the net to be towed at a depth of from 500 to 570 fathoms. We found in this case in the bottom part of the net, which came up tightly closed, a Scopelus, a Penæid, and a Hyalea, while the upper open part of the net contained the same surface species we had obtained before.

My experience in the Gulf of California with the Tanner selfclosing net would seem to indicate that in a comparatively closed sea, at a small distance from the land, there may be a mixture of the surface species with the deep-sea bottom species, a condition of things which certainly does not exist at sea in an oceanic basin at a great distance from shore, where the surface pelagic fauna only descends to a comparatively small depth-about 200 fathoms-the limits of the depth at which light and heat produce any considerable variation in the physical condition of the water. The marked diminution in the number of species below 200 fathoms agrees fairly with the results of the National Expedition.

The more I see of the Albatross the more I become convinced that her true field is that of exploration. She is a remarkably fine sea boat, and has ample accommodation for a staff of working specialists such as would be needed on a distant expedition. The time will soon come when the Fish Commission will hardly care to continue to run her, and I can conceive of no better use for so fine a vessel than to explore a beit of $20^{\circ}$ latitude north and south of the equator in the Pacific, from the west coast of Central America to the East Indian Archipelago.

The success of the Albatross thus far has depended entirely upon the zeal, energy, intelligence, forethought, and devotion of Captain Tanner, if I may judge of the past by the present. $\mathrm{He}$ never spares himself, and he is always ready to make the most of the time at his disposal for the benefit of the special object he has in charge. He looks after every haul of the trawl himself, and will not allow anyone else to jeopard in any.way the material of the vessel, or the time it requires to make a haul. That responsibility he assumes himself, and it constitutes his daily work. In looking over the records of the Albatross during her voyage from New York to San Francisco, I am struck with the amount of work which has been accomplished. It would be but a just return to Captain Tanner if Congress would make the necessary appropriations to work up and publish all that he has brought together, not only on that cruise, but also what has been left untouched thus far of the immense collections made by him in the Caribbean, and off the east coast of the Uniter States, to say nothing of his explorations in the Gulf of California, on the coast of California, on the coast of Alaska, and in the Behring Sea, from which he has accumulated endless and most interesting material, which no other ship could get together unless she had another Tanner in command.

We reached Guaymas on April 23, in the afternoon, and I parted from the ship with great regret, but more than satisfied with the results of this expedition.

Allow me, in concluding, to thank you most cordially for having given me the opportunity to join the Albatross on this extended cruise, and for your kindness in urging the President to allow the vessel to be detailed for this work.

As soon as it may become practicable, I shall send you a full résumé of our work, accompanied with sketches of the Tanner tow-net and a detailed chart of the route we followed.

Very respectfully yours,

Alexander Agassiz.

\section{THE ORIGIN OF THE ASS, THE CAT, AND THE SHEEP IN CHINA.}

$\mathrm{A}^{\mathrm{T}}$ a recent meeting of the China Branch of the Royal Asiatic Society in Shanghai, Dr. Macgowan, a well-known Chinese scholar, read a paper on the probable foreign origin of the ass, the cat, and the sheep in China. He said that the Chinese, in their numerical co-ordination of concrete and abstract nature, give the "six domestic animals" as the horse, ox, goat, pig, dog, and fowl; which seems to indicate that when that formula was framed, neither cat, sheep, nor ass had been domesticated there. When familiar beasts were selected to denote years of the duodenary cycle, to the "six domestic animals" were added the rat, tiger, hare, dragon, serpent, and monkey, to complete the dozen, as if the ass, sheep, and cat were too little known to meet the object in view, which was the employment of the most familiar representations of animated nature for the duodendary nomenclature. Still more striking is the absence of the ass, sheep, and cat from the twenty-eight zodiacal constellations, which are represented by the bestknown animals.

With regard to the ass, there is ample reason to regard it as being excluded from the list of domestic animals because it was not archaic. The hybrid mule is of comparatively modern origin in China, dating back only about a score of centuries. A miscellany of the Sung era states that "the mule was not seen during the Hsai, Shang, and Chou dynasties; that it was a cross between the ass and horse from Mongolia. It is regularly bred in the north, and is worth in the market twice as much as the horse ; it is popularly reported that its bones are marrowless, which is the reason of its inability to produce its kind." Again, it is recorded in a Ming cycloprdia: "The mule is stronger than the horse, and is not a natural product of China ; in the Han era it was regarded as a remarkable domestic animal." Is it likely that, if the ass existed during the three ancient dynasties, there was no crossing with the horse?

With regard to the cat, Dr. Macgowan proceeded to state that there was a quotation from a standard work which dis-

No. 1 I 60, vor. 45$]$ 
closes the fact that Yuang Chuang, the pilgrim monk, who, in the seventh century A.D., returned after sixteen years' wanderings in India, brought cats with him to protect his collection of Sanskrit Buddhist books from rats. That account, however, is somewhat invalidated by an anecdote of Confucius, who is related to have one day seen a cat chasing a rat. These conflicting statements are from authoritative sources, and it is impossible to offer a satisfactory explanation. Possibly the cat of Confucian times was only a partially domesticated wild cat. There must have been some ground for the statement of the cat having been brought from India, as it is hardly likely that in all the long period of Chinese history it should be named but twice as a domestic animal. He quotes from Chinese folk-lore on the subject of cats. As cruelty to cats and other animals is followed by retribution, so services rendered to them meet with supernal recognition. As anciently the tiger was sacrificed to because it destroyed wild boars, so the wild cat was worshipped because it was the natural foe of rats; boars and rats being the natural enemies of husbandry. At the commencement of the Sui dynasty (A.D. $5^{8} \mathrm{I}$ ), the cat spirit inspired greater terror than the fox did subsequently. The hallucinations of cat spirit mania prevailed, forming a remarkable episode in Chinese history, only to be likened to the fanatical delusion of witchcraft that frenzied Europe a thousand years later. It was believed that the spirit of a cat possessed the power of conjuring away property from one person to another, and inflicted through incantations bodily harm. The popular belief was intensified and spread like an epidemic, until every disastrous affair that took place was ascribed to cat spirit agency set in motion by some mischievous enemy. Accusations were lodged against suspected persons, and, the slightest evidence sufficing for conviction, the malicious were encouraged to trump up charges against the innocent, until the country became a pandemonium. No one was safe, from the Imperial family down to the humble clodhopper. Even a magnate of the reigning house, who enjoyed the titular distinction of Prince or King of Szechuan, was executed for nefariously employing the agency of cat spirits. In this manner several thousands were immolated before the delusion was dispelled. Happily the period appears to have been of brief duration : incentives such as kept up the witch mania for centuries were wanting in China. Coming down to our own times we find a cat-craft delusion prevailed over a great portion of Chêkiang. " In the summer and autumn of 1847 frightful wraiths appeared throughout the departments of Hangchow, Shaohsing, Ningpo, and Taichow. They were demons and three-legged cats. On the approach of night a fœild odour was perceptible in the air, when dwellings were entered by something by which people were bewitched, causing alarm everywhere. On detecting the effluvium in the air, householders commenced gong-beating, and the sprites, frightened by the sonorous noise, quickly retreated. This lasted for sveral months, when the weird phenomena ceased." Well did he remember, said Dr. Macgowan, the commotion that prevailed in Ningpo throughout those months of terror. Every gong that could be procured or manufactured for the occasion was subject to vigorous thumping through the livelong night, maintained with vociferations by relays of zealous beaters. This deafening din was but a recrudescence of what had occurred a few generations before-a panic which was only exceeded by that which subsequently prevailed over the entire empire.

With regard to sheep, Dr. Macgowan said the ancient mode of writing the character for yang, goat, was ideographic-four strokes on the top to represent horns, two horizontal strokes representing legs, and a perpendicular one to represent body and tail. The modern form gives an additional parallel stroke, like the word for horse ; it is a simple not a compound character, and when sheep came to be known, instead of making a new character, the sheep was called the "Hun-goat," thus indicating its origin and affinity. Yang, goat, is often translated sheep, the earliest instances being found in one of the Odes, wherein the Court habiliments of Wen Wang are called "lamb-skins and sheep-skins." This was about I 60 R.C., but it is doubtful if these robes are really the skins of sheep. It is not certain that such was the case, for the skins of goats were used then, as now, for clothes. Hun-goats are not named before the period of the Tang dynasty, say the seventh century A.D. The goat was one of the sacrificial animals, as at present, and was at the first selected for sacrifice when sheep were unknown.
In the discission which followed, the conclusions of the paper were not accepted by all the speakers; and it was agreed that the subject was one worthy of scholarly investigation.

\section{$H A I N A N$}

THE great island of Hainan, off the south-eastern coast of China, is but little known to Europeans, although since 1877 there has been a treaty port there. Mr. Parker, the Consulat Kiungchow, the port in question, lately made a short journey in the interior of the island, of which he gives some account in a recent report. $\mathrm{He}$ travelled about sixty miles up the Poh-Chung River, to within a mile or two of Pah-hi, which is, at most seasons of the year, considered the limit of navigation for all but the smallest craft. He walked round the walls of Ting-an city, one of the disturbed districts during the recent rebellions, ou New Year's Day (February 9); they are just one mile in circuit, and differ little from those of other Chinese cities. Wherever he had an opportunity of walking diametrically across lengthy curves of the river he found the inclosed area to be extremely well cultivated; though not so flat, its general appearance recalled many features of the Tonquin delta, especially in its great wealth of bamboos. The productions of the soil are much the same, the papaw, areca-palm, sweet potato, turnip, ground-nut, orange-tree, \&c. ; but a peculiar Hainan feature is the cocoa-nut palm. Another peculiarity of this region is the ubiquitousness of the dwarf Pandanus, probably the same as the $P$. odoratissima of Fiji, the fibre of which is used in the manufacture of grass-cloth, and is usually known to foreign trade here as hemp. Much of the land was under sweet potato cultivation, and every household seemed to possess a few pigs, of the very superior and stereotyped Hainan variety, black as to the upper and white as to the lower part of the body, with a dividing line of grey running along the side from the snout to the tail. These wholesome-looking pigs are fattened on the sweet potato, and do not rely for sustenance upon precarious scavengering, as is the case with the repulsive and uncleanly animals of North China. Land contiguous to the river is irrigated by enormous wheels, forty feet in diameter, of very ingenious construction, moved by the current, needing no attention, and discharging perhaps one hundred gallons of water in a minute into the trough above, day and night without intermission. He passed several large pottery establishments; but as at the New Year all business and cultivation are suspended for a few lays, the opportunity was not a very good one for gathering precise information. The temperature during the week ranged between $50^{\circ}$ and $60^{\circ} \mathrm{F}$. Game seemed plentiful everywhere, and he mentions that a German resident has recently made a very fine collection of about 400 Hainan birds, embracing 154 species, which will shortly be on their way to a Berlin Museum. One of the commonest birds in the river is a spotted white and black kingfisher of large size. Amongst the trees which attracted his attention was one locally called the "great-leafed banyan," which looks remarkably like the gutta-percha tree; the natives seem to use its gum mixed with gambier, in order to make that dye "fast"; but there is some doubt whether it is not the sap of the real banyan-tree which is used for the purpose. A very strong silk is made from the grub called the "celestial silkworm," or, locally, "paddy-insect." This grub is found on a sort of maple. When full-grown it is thrown into boiling vinegar, on which the " head" of the gut, or "silk," appears; this is sharply torn out with both hands drawn apart, and is as long as the space between them, say five feet; it is so strong that one single thread of it is sufficient to make a line with which to catch the smaller kinds of fish.

\section{UNIVERSITY AND EDUCATIONAL INTELLIGENCE.}

OXFORD.-The Chancellor of the University, acting as Visitor of Pembroke College, has appointed the Rev. Bartholomew Price, M.A., F.R.S., Senior Fellow, and Vicegerent of the College, Sedleian Professor of Natural Philosophy, to be Master of the College in the place of the late Dr. Evans. Prof. Price, whose contributions to mathematics are well known, has long taken a leading part in University business, and his appointment to the Mastership of the College, of which he has been a Fellow since 1843 , will be warmly approved. 